\title{
Online Examination Service using Mobile Application
}

\author{
B.Sundarraj, S. Pothumani, N. Priya
}

\begin{abstract}
Day-to-day life has been changed a lot. Each and everything is held through internet and many institutions, companies works through internet. Most advantages or helpful by internet is, having exam through online (or) internet. So we can write or attend the exam anywhere anytime. To make this, we need cloud concept too. In cloud, we create own cloud and store the data for exam, so a person can access data from cloud through internet anytime. And mobile application is also being trend now, so many applications of this is possible to make it out. Keywords:
\end{abstract}

Exam, Online, Student, Database, Web Service, Administrator

\section{INTRODUCTION}

\section{INTRODUCTION:}

In mobile application, the service is same as which we use in computer based online service except the coding which we used for mobile application is android and for pc based could be java or any other language. Now, we are going to use android for mobile based application and java for pc based service. In this actually, we use the service of online exam. In which according to the subject choose, the related questions are displayed and the time taken for the completion of exam and score is displayed and sent as alert message for the student. All this are done through internet only. [31],[33],[35]

\section{A. Existing System}

The generation of questions could be ManualWork. [1], [ 3],[5]The Previous work for conducting examination need large man power to prepare that appear in the question paper. Tutors and Instructors choose the questions based on syllabus and pattern as prescribed by the given notes. This should may be send to managementand get approvals.

B. Limitations in existing system

Most of the manual work, previous system may be affected due to manual intervention. this may cause the redundancy. and also scarcity of resources and non availability, natural disasters and

Revised Manuscript Received on July 22, 2019

B.Sundarraj, Department of Computer Science and Engineering, Bharath Institute of Higher education and research, Chennai , India

S. Pothumani, Department of Computer Science and Engineering, Bharath Institute of Higher education and research, Chennai , India

Ms. N. Priya,, Department of Computer Science and Engineering, Bharath Institute of Higher education and research, Chennai , India authentication issues. as many human work cause issues. So there is no assurance for unique questions.. Other limitations include: - a) Insufficient memory b) Chances to break c) Issues to transferring messages d) Huge costs e) Infrastructure set up issues f) Distribution Problem g) Updating issues. [38],[40],[42]

\section{Drawback in Existing System:}

1. Major drawback in existing system for examination system is ,requires huge amount of papers .

2. Requires a human staff for distribution of question paper everytime.

3. May be problems occur by printing machines.

4. Storing the papers required large amount of space .

D. Advantages of Proposed System:

1. The main advantage of online exam system is that student can attend the exam anywhere.

2. Human effort is heavily reduced.

3. Result of the exam is shown immediately after completion of exam.

4. We can reduce the paper usage heavily.

The scope and limitation of this system is:

- The on-line exam system design to educational institutes.

- Hold all operation and generate reports to student, teachers and administrator.

- Support multiple choices questions.

- Allow the student to prochoice the answer and to see his mark.

- Verify a security, authority and safety.

\begin{tabular}{|c|c|c|}
\hline \multicolumn{3}{|c|}{ Glossary: } \\
\hline & Short tene & descaption \\
\hline 1 & CES & Oa.line Esre Swstem \\
\hline 2 & Oe-line Exa & 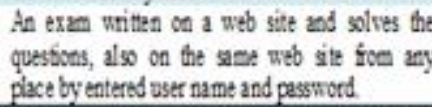 \\
\hline & Adruinistator & $\begin{array}{l}\text { Who is responstble to create a nem coust, delete } \\
\text { course, add member or deleste it i.e. be persoc } \\
\text { who control the system }\end{array}$ \\
\hline
\end{tabular}

\section{E. Easy to store and retrieve information:}

Rather to save the information on a papers or in separate sheets. There are a data base management to store and retrieve the information needed by the administrator or Faculty member or student according a report generated by 
the system. [2 ], [4],[6] Hardware Personal computer, mobile.

\section{F.Modules:}

Module 1: Login form, users can login into their account by using this login form and only if already registered users can login this page by giving their username and password.

If the user is new, then he can register his name, personal details and other required details through registration form and then he can login into his account through login form page. [32],[34],[36]

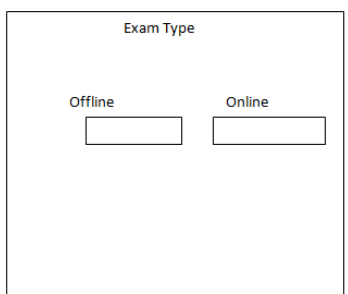

Module 3: Exam module, in this module firstly they
can choose the subject and they can proceed. Afte selecting the subject, the questions related to the subject is displayed on the fom. This is done when
student selects option exam through offine.

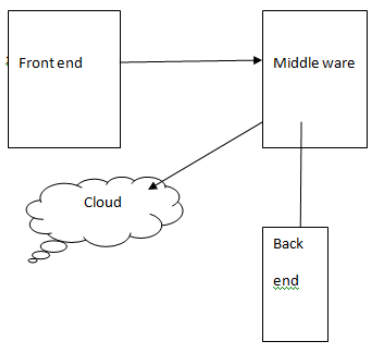

\section{ALGORITHM AND METHOD SPECIFICATION}

1. Create a login page for administrator.

2. Create a menu form for administrator and give the necessary buttons links.

3. Now create a login page and registration page for student.

4. If a student is new then go to registration page and give the necessary details.

5. If a student is already registered then student can goto login page directly.

6. Create an interface to choose the type of exam to write by student i.e.,online or offline.

7. If a students choose offline as exam then create a page for choosing a subject to write an exam by student.

8. Now create an interface to load the questions after selecting the subject

9. If a student chooses online as exam type then he must choose the link in the related page.

10. Create a cloud for storing the online questions.

And create the database to store all questions and answers. [25],[27],[29]

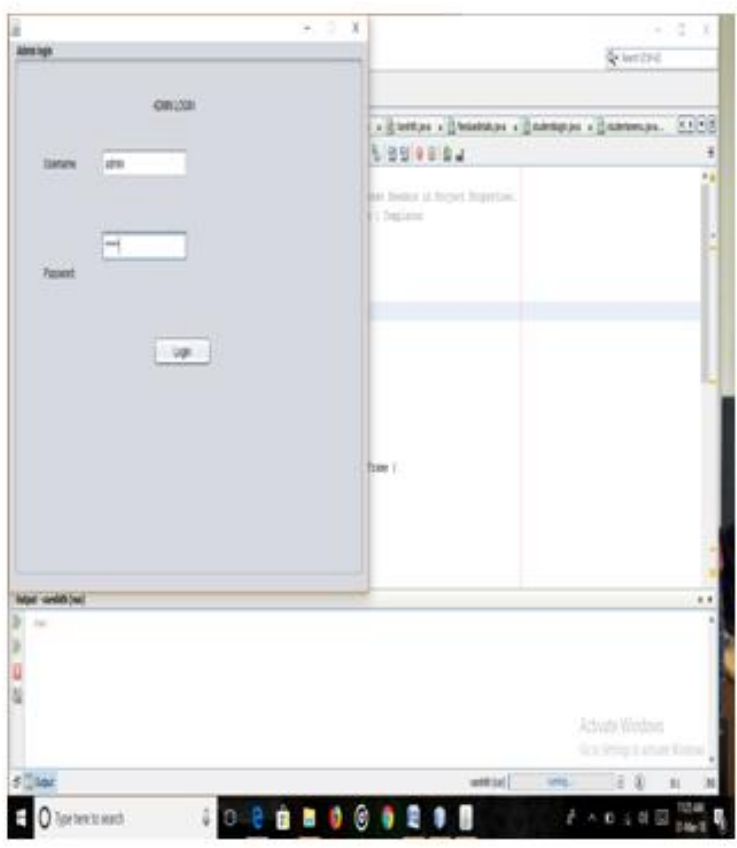

Fig, Admin Login Form

V SYSTEM IMPLEMENT ATION

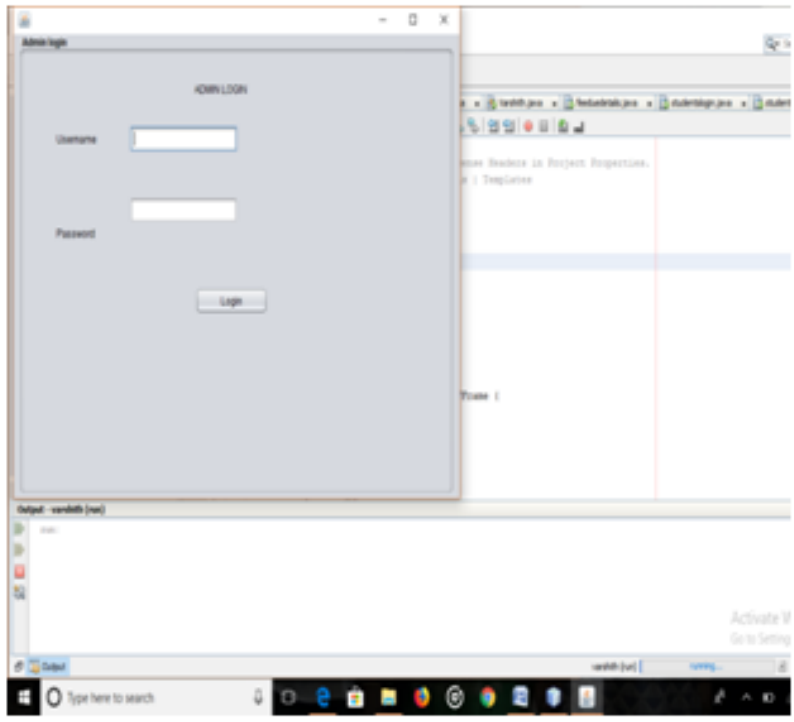

Fig. Admin Form 


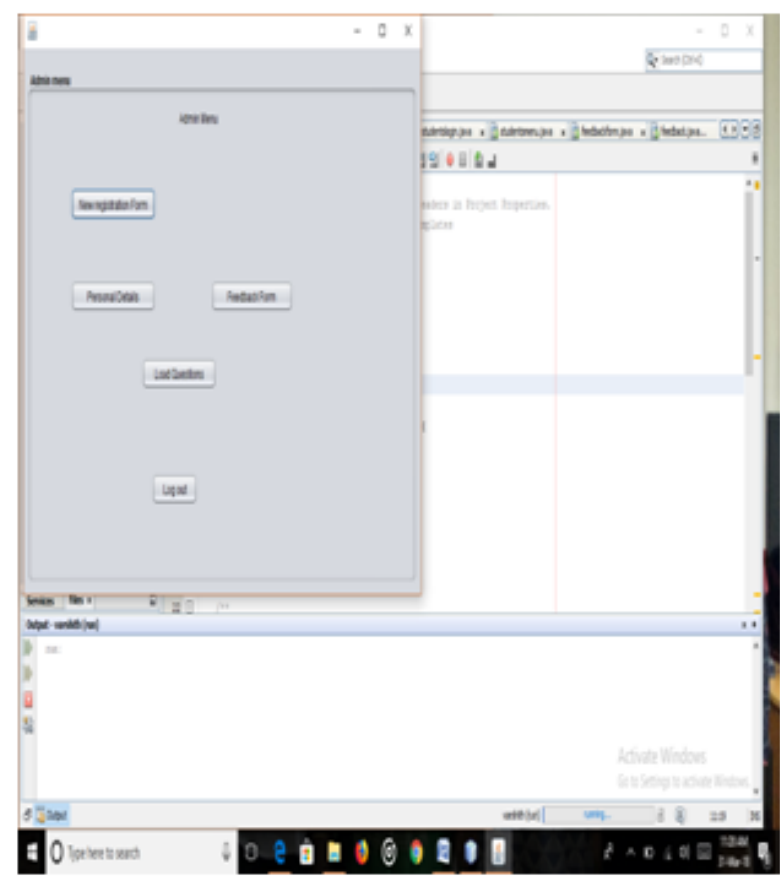

Fig, Admin Menu Form

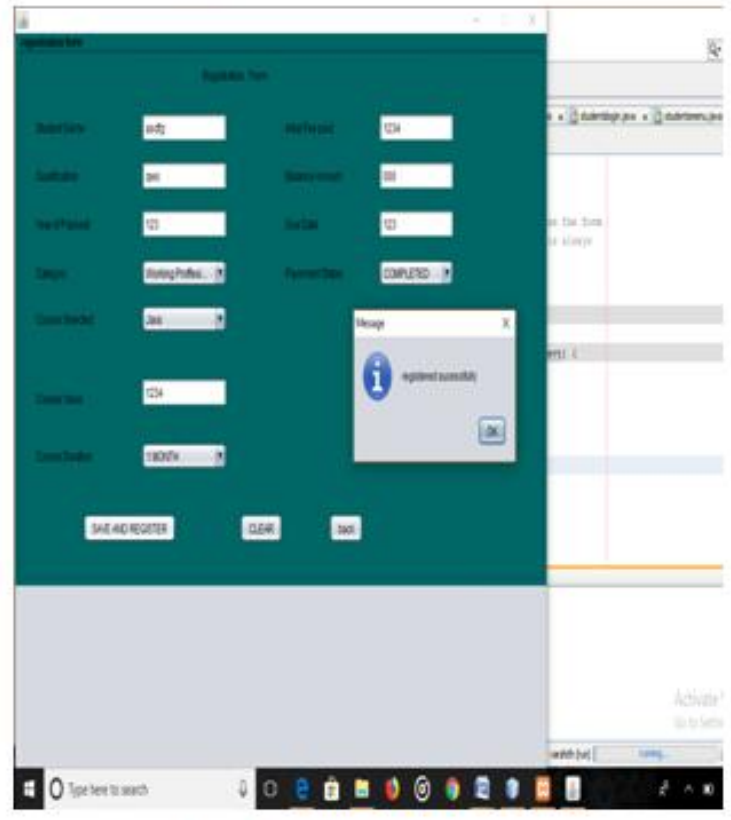

Fig, Registration Form

\section{REFERENCES}

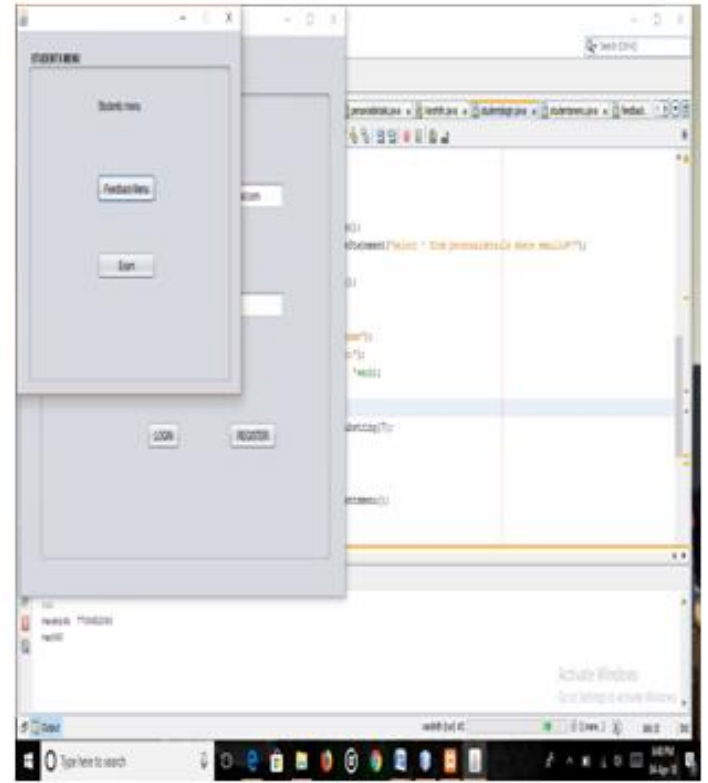

Fig, Students Menu Form

\section{CONCLUSION}

The online examination system was analyzed and designed successfully to implement and test by including programming languages, databases, cloud in it to achieve the bugs free application for user . [19],[21],[23]
[1] A., Rangarajan K.,Algorithm for automaton specification for exploring dynamic labyrinths,Indian Journal of Science and Technology,V-6,I-SUPPL5,PP-4554-4559,Y-2013

[2] P. Kavitha, S. Prabakaran "A Novel Hybrid Segmentation Method with Particle Swarm Optimization and Fuzzy C-Mean Based On Partitioning the Image for Detecting Lung Cancer" International Journal of Engineering and Advanced Technology (IJEAT) ISSN: 2249-8958, Volume-8 Issue-5, June 2019

[3] Kumaravel A., Meetei O.N.,An application of non-uniform cellular automata for efficient cryptography,2013 IEEE Conference on Information and Communication Technologies, ICT 2013,V-,I-,PP-1200-1205,Y-2013

[4] Kumarave A., Rangarajan K.,Routing alogrithm over semi-regular tessellations,2013 IEEE Conference on Information and Communication Technologies, 2013,V-,I-,PP-1180-1184,Y-2013

[5] P. Kavitha, S. Prabakaran "Designing a Feature Vector for Statistical Texture Analysis of Brain Tumor" International Journal of Engineering and Advanced Technology (IJEAT) ISSN: 2249-8958, Volume-8 Issue-5, June 2019

[6] Dutta P., Kumaravel A.,A novel approach to trust based identification of leaders in social networks,Indian Journal of Science and Technology,V-9,I-10,PP--,Y-2016

[7] Kumaravel A., Dutta P.,Application of Pca for context selection for collaborative filtering,Middle - East Journal of Scientific Research,V-20,I-1,PP-88-93,Y-2014

[8] Kumaravel A., Rangarajan K.,Constructing an automaton for exploring dynamic labyrinths,2012 International Conference on Radar, Communication and Computing, ICRCC 2012,V-,I-,PP-161-165,Y-2012

[9] P. Kavitha, S. Prabakaran "Adaptive Bilateral Filter for Multi-Resolution in Brain Tumor Recognition" International Journal of Innovative Technology and Exploring Engineering (IJITEE) ISSN 2278-3075, Volume-8 Issue-8 June, 2019

[10] Kumaravel A.,Comparison of two multi-classification approaches for detecting network attacks,World Applied Sciences Journal,V-27,I-11,PP-1461-1465,Y-2013

[11] Tariq J., Kumaravel A.,Construction of cellular automata over hexagonal and triangular tessellations for path planning of multi-robots,2016 IEEE International Conference on Computational Intelligence and Computing Research, ICCIC 2016,V-,I-,PP--,Y-2017 
[12] Sudha M., Kumaravel A.,Analysis and measurement of wave guides using poisson method,Indonesian Journal of Electrical Engineering and Computer Science,V-8,I-2,PP-546-548,Y-2017

[13] Ayyappan G., Nalini C., Kumaravel A., Various approaches of knowledge transfer in academic social network,International Journal of Engineering and Technology,V-,I-,PP-2791-2794,Y-2017

[14] Kaliyamurthie, K.P., Sivaraman, K., Ramesh, S. Imposing patient data privacy in wireless medical sensor networks through homomorphic cryptosystems 2016, Journal of Chemical and Pharmaceutical Sciences 92.

[15] Kaliyamurthie, K.P., Balasubramanian, P.C. An approach to multi secure to historical malformed documents using integer ripple transfiguration 2016 Journal of Chemical and Pharmaceutical Sciences 92.

[16] A.Sangeetha,C.Nalini,'Semantic Ranking based on keywords extractions in the web", International Journal of Engineering \& Technology, 7 (2.6) (2018) 290-292

[17] S.V.GayathiriDevi,C.Nalini,N.Kumar,"An efficient software verification using multi-layered software verification tool "International Journal of Engineering \& Technology, 7(2.21)2018 454-457

[18] C.Nalini,ShwtambariKharabe,"A Comparative Study On Different Techniques Used For Finger - Vein Authentication", International Journal Of Pure And Applied Mathematics, Volume 116 No. 8 2017, 327-333, Issn: 1314-3395

[19] M.S. Vivekanandan and Dr. C. Rajabhushanam, "Enabling Privacy Protection and Content Assurance in Geo-Social Networks", International Journal of Innovative Research in Management, Engineering and Technology, Vol 3, Issue 4, pp. 49-55, April 2018.

[20] Dr. C. Rajabhushanam, V. Karthik, and G. Vivek, "Elasticity in Cloud Computing", International Journal of Innovative Research in Management, Engineering and Technology, Vol 3, Issue 4, pp. 104-111, April 2018.

[21] K. Rangaswamy and Dr. C. Rajabhushanamc, "CCN-Based Congestion Control Mechanism In Dynamic Networks", International Journal of Innovative Research in Management, Engineering and Technology, Vol 3, Issue 4, pp. 117-119, April 2018.

[22] Kavitha, R., Nedunchelian, R., "Domain-specific Search engine optimization using healthcare ontology and a neural network backpropagation approach”, 2017, Research Journal of Biotechnology, Special Issue 2:157-166

[23] Kavitha, G., Kavitha, R., "An analysis to improve throughput of high-power hubs in mobile ad hoc network", 2016, Journal of Chemical and Pharmaceutical Sciences, Vol-9, Issue-2: 361-363

[24] Kavitha, G., Kavitha, R., "Dipping interference to supplement throughput in MANET" , 2016, Journal of Chemical and Pharmaceutical Sciences, Vol-9, Issue-2: 357-360

[25] Michael, G., Chandrasekar, A.,"Leader election based malicious detection and response system in MANET using mechanism design approach", Journal of Chemical and Pharmaceutical Sciences(JCPS) Volume 9 Issue 2, April - June 2016.

[26] Michael, G., Chandrasekar, A.,'Modeling of detection of camouflaging worm using epidemic dynamic model and power spectral density", Journal of Chemical and Pharmaceutical Sciences(JCPS) Volume 9 Issue 2, April - June 2016 .

[27] Pothumani, S., Sriram, M., Sridhar, J., Arul Selvan, G., Secure mobile agents communication on intranet,Journal of Chemical and Pharmaceutical Sciences, volume 9, Issue 3, Pg No S32-S35, 2016

[28] Pothumani, S., Sriram, M., Sridhar , Various schemes for database encryption-a survey, Journal of Chemical and Pharmaceutical Sciences, volume 9, Issue 3, Pg NoS103-S106, 2016

[29] Pothumani, S., Sriram, M., Sridhar, A novel economic framework for cloud and grid computing, Journal of Chemical and Pharmaceutical Sciences, volume 9, Issue 3, Pg No S29-S31, 2016

[30] Priya, N., Sridhar, J., Sriram, M. "Ecommerce Transaction Security Challenges and Prevention Methods- New Approach” 2016 ,Journal of Chemical and Pharmaceutical Sciences, JCPS Volume 9 Issue 3.page no:S66-S68 .

[31] Priya, N.,Sridhar,J.,Sriram, M."Vehicular cloud computing security issues and solutions" Journal of Chemical and Pharmaceutical Sciences(JCPS) Volume 9 Issue 2, April - June 2016

[32] Priya, N., Sridhar, J., Sriram, M. "Mobile large data storage security in cloud computing environment-a new approach” JCPS Volume 9 Issue 2. April - June 2016

[33] Anuradha.C, Khanna.V, "Improving network performance and security in WSN using decentralized hypothesis testing "Journal of Chemical and Pharmaceutical Sciences(JCPS) Volume 9 Issue 2, April - June 2016.

[34] Anuradha.C, Khanna.V, "A novel gsm based control for e-devices"
Journal of Chemical and Pharmaceutical Sciences(JCPS) Volume 9 Issue 2, April - June 2016

[35] Anuradha.C, Khanna.V, "Secured privacy preserving sharing and data integration in mobile web environments " Journal of Chemical and Pharmaceutical Sciences(JCPS) Volume 9 Issue 2, April - June 2016.

[36] Sundarraj, B., Kaliyamurthie, K.P. Social network analysis for decisive the ultimate classification from the ensemble to boost accuracy rates

2016 International Journal of Pharmacy and Technology 8

[37] Sundarraj, B., Kaliyamurthie, K.P. A content-based spam filtering approach victimisation artificial neural networks 2016 International Journal of Pharmacy and Technology $8 \quad 3$.

[38] Sundarraj, B., Kaliyamurthie, K.P. Remote sensing imaging for satellite image segmentation 2016 International Journal of Pharmacy and Technology 83.

[39] Sivaraman, K., Senthil, M. Intuitive driver proxy control using artificial intelligence 2016 International Journal of Pharmacy and Technology 84.

[40] Sivaraman, K., Kaliyamurthie, K.P. Cloud computing in mobile technology 2016 Journal of Chemical and Pharmaceutical Sciences 92.

[41] Sivaraman, K., Khanna, V. Implementation of an extension for browser to detect vulnerable elements on web pages and avoid click jacking 2016 Journal of Chemical and Pharmaceutical Sciences 92.

\section{AUTHORS PROFILE}

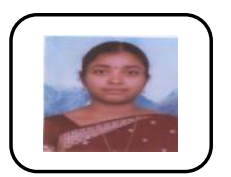

B. Sundarraj, Assistant Professor, Department of Computer Science \& Engineering, Bharath Institute of Higher Education and Research, Chennai, India

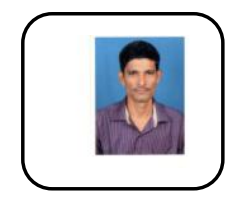

S. Pothumani, Assistant Professor, Department of Computer Science \& Engineering, Bharath Institute of Higher Education and Research, Chennai, India

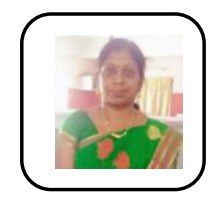

N.Priya, Assistant Professor, Department of Computer Science \& Engineering, Bharath Institute of Higher Education and Research, Chennai, India 